\title{
PRODUCTIVITY POTENTIAL AND SOME MECHANICAL WOOD PROPERTIES FOR 36-YEAR- OLD Khaya senegalensis GROWN BY TWO DIFFERENT PLANTATION METHODS IN ASWAN, EGYPT
}

Ebeid, A. F. A.; R. M. M. Sayed; Mona M. A. Mostafa

Dept. of Forestry, Horticultural Res. Inst., Agric. Res. Center, Egypt.

\begin{abstract}
Aboveground- tree biomass and mechanical wood properties were measured in 36- year- old trees of Khaya senegalensis A. Juss. either as an experimental area or as a single- tree row, grown on infertile soil in the Tropical Farm of Kom- Ombo, Aswan Botanical Garden, Hort. Res. Inst., Agric. Res. Center, Egypt. Khaya senegalensis grown as a single row had the highest values of total stem volume, diameter at breast height and merchantable height as well as weights of leaves, twigs up to $1 \mathrm{~cm}$ diameter and branches up to $5 \mathrm{~cm}$ diameter compared to that grown in plantations at $5 \times 5 \mathrm{~m}$ spacing. Data revealed that, the productivity potential of 36 -yearold Khaya senegalesnis grown under Aswan conditions at $5 \times 5 \mathrm{~m}$ spacing was about $300.7 \mathrm{~m}^{3} / \mathrm{fed}, 61.8 \mathrm{ton} / \mathrm{fed}, 61.9 \mathrm{ton} / \mathrm{fed}$ and $34.3 \mathrm{ton} / \mathrm{fed}$ for the total stem volume, branches up to $5 \mathrm{~cm}$ diameter, twigs up to $1 \mathrm{~cm}$ and fresh leaves, respectively. On the other hand, the mechanical properties of Khaya senegalensis planted in this region were comparable of a number of valuable hardwood species grown in different countries. Khaya senegalensis as plantations in this study showed a high potential for producing wood with higher values for modulus of rupture (MOR), modulus of elasticity (MOE), compression parallel to grain and maximum shearing of strength than that of trees in a single row.
\end{abstract}

Keywords: Aboveground biomass, Khaya senegalensis, mechanical properties, plantations, single- tree row.

\section{INTRODUCTION}

Quantitative estimation of aboveground biomass is important to measure stand production consisting of stem, branch wood and leaves. Height and diameter of a tree are the major parameters that determine the harvestable wood. However, forest biomass and its change over time have long been considered as key characteristics of forest ecosystems (Cannell, 1982). Biomass assessment is important for many purposes. It is aimed at two major objectives: (1) for resource use and (2) for environmental management (Parresol, 1999). It is important to determine how much fuel wood or timber is available for use. Biomass is also an important indicator in carbon sequestration. For this purpose, one needs to know how much biomass is lost or accumulated over time. Consequently, the amount of carbon sequestered can be inferred from the biomass change since $50 \%$ of the forest dry biomass is carbon (Losi et al., 2003).

El- Morshedy et al. (1996) evaluated the biomass production of Khaya senegalensis in the same plantations of our study, but for trees at 28-yearold. They stated that diameter at breast height, total height, total stem volume and branches fresh weight for the plantation area were $34.0 \mathrm{~cm}, 11.5 \mathrm{~m}, 1.05$ 
Ebeid, A. F. A. et al.

$\mathrm{m}^{3} /$ tree and $215 \mathrm{~kg} /$ tree, while that grown as a single- tree row produced $67.0 \mathrm{~cm}, 18.9 \mathrm{~m}, 3.81 \mathrm{~m}^{3} /$ tree and $645 \mathrm{~kg} /$ tree for these characters, respectively. Recently, Nasser et al. (2010) worked on 9- year- old Melia azedarach. They revealed that means of total height, diameter at breast height, stem volume, total fresh biomass and total dry biomass were $6.56 \mathrm{~m}$, $22.98 \mathrm{~cm}, 0.36 \mathrm{~m}^{3} /$ tree, $287.5 \mathrm{~kg} /$ tree and $165.4 \mathrm{~kg} /$ tree, respectively.

Wood is one of the oldest engineering materials in the world, which can be used for a variety of purposes, including constructions, furniture, pulp and papers, as well as extractive chemical products. On the other hand, variability, or variation in properties, is common to all materials. Because wood is a natural material and the tree is subject to many constantly changing influences (such as moisture, soil conditions, and growing space), wood properties vary considerably, even in clear material (Kretschmann and Green, 1996). In this respect, mechanical properties are usually the most characteristics of wood products to be used in different purposes as in structural applications.

Mechanical properties most commonly measured and represented as "strength properties" for design include modulus of rupture in bending, maximum stress in compression parallel to grain, compressive stress perpendicular to grain, and shear strength parallel to grain (Mallory and Gramer, 1987). In this respect, Josue (2004) studied the mechanical properties of Xylia xylocarpa as a hardwood species and a fast growing tree. $\mathrm{He}$ reported that the means of modulus of rupture (MOR), modulus of elasticity (MOE), compression parallel to grain and shear parallel to grain were $134.8,12861,68.3$ and $18.9 \mathrm{~N} / \mathrm{mm}^{2}$, respectively. On the other hand, Guler et al. (2007) studied the mechanical properties of Pinus nigra as a softwood species. They found that the mechanical tests resulted in that the static bending and compression strengths were 79.1 and $42.4 \mathrm{~N} / \mathrm{mm}^{2}$, respectively.

Khaya senegalensis A. Juss. belongs to family Meliaceae is a semideciduous tree, 20-35 m high, up to $1 \mathrm{~m}$ diameter, with a clean bole to 8-10 $\mathrm{m}$. The timber of this species was the first known of the African mahoganies. Young leaves contain fairly large amounts of digestible crude protein. The leaves are used as fodder for cattle and camels, although they are not very palatable. The wood is used in West Africa for pulp. Its timber is one of the hardest African mahoganies and the hardest of the Khaya species (Sahni, 1968). It is widely used on a commercial scale, particularly in West Africa. It is favoured for furniture, high- class joinery, flooring, turnery and veneer. Because of its decorative appearance, the wood of $K$. senegalensis is very popular timber. Therefore, this study aimed to examine the above- ground biomass and some of wood mechanical properties of $K$. senegalensis, which has been planted 36 years ago in Aswan- Egypt. 


\section{MATERIALS AND METHODS}

\section{Above-ground biomass determination:}

This study was done on trees located at Kom-Ombo Tropical Farm, Aswan Botanical Garden, Hort. Res. Inst., Agric. Res. Center, Egypt during 2010 season. The soil at this site was characterized as loamy sand, $\mathrm{pH} 8.4$, organic matter $0.45 \%$ and EC 0.31 . In 2010 samples were selected from 36$y$ - old trees of Khaya sensgalensis A. Juss., replicated plots planted at $5 \times 5 \mathrm{~m}$ spacing with 15 trees per plot. Five sample trees per plot were randomly selected from each of the four replications for a total of 20 sample trees per the site. In addition, thirty- one trees grown as a single- row in the same field at $5 \mathrm{~m}$ spacing ( spacing between row was $5 \mathrm{~m}$ ) and five trees were selected to represent the single row.

\section{Sample trees:}

Prior to tree cutting, diameter at breast height $(\mathrm{DBH})$ was measured using diameter tape. DBH is the stem diameter at $1.3 \mathrm{~m}$ above the ground (FAO, 2004b). For trees with enlargement or buttress, the diameter was measured at $30 \mathrm{~cm}$ above the main enlargement (FAO, 2004b). Height of the tree was measured with measuring tape after cutting the tree. The sample tree was segregated into fractions: leaves, twigs (diameter up to $1 \mathrm{~cm}$ ), small branches (diameter up to $5 \mathrm{~cm}$ ) and stem (Ketterings et al., 2001). The segregation is important because of the systematic difference in moisture content along the length of the tree. The stem diameter and height were measured to get an estimate of its volume and dry weight as described below. For stem, diameter was measured every two meters length. This measurement was used for stem volume and dry weight estimation. Wood subsamples were then selected from the stem: one each in the lower, middle and upper portion. These wood samples were also collected from each twigs and small branches. Three leaf samples, of $100 \mathrm{~g}$ each, were also collected for each tree sample. The wood samples were stored in a sealed plastic bag to retain moisture prior to measurement of fresh weight done on the evening of collection date.

\section{Volume and dry weight estimation:}

For volume determination of stem since the stem represents the main portion of the total tree above- ground biomass, stem wood samples were saturated with water, and then the volume was measured by water displacement. The wood and leaf samples were also oven-dried at $105^{\circ} \mathrm{C}$ until constant weight (Kettering et al., 2001).

The volume of each stem section was calculated using Samilian's formula (de Gier, 2003). The total stem volume was computed as the sum of the calculated stem section volume.

Vol=n/8 $\left(D^{2}+d^{2}\right) \times I$. Where, vol= volume of the stem section, $l=$ length of the section, $D=$ diameter of the larger end of the stem section, and $d=$ diameter of the smaller end of the stem section.

The stem volume was converted into dry weight using the formula of Jarayaman (2000). 
$D W_{f}=F_{f} \times D W_{s} / F V_{s}$. Where, $D W_{f}=$ dry weight of the stem, $F V_{f=}$ fresh volume of stem, $\mathrm{DW}=$ dry weight of the subsample of the stem, and $\mathrm{FV}_{\mathrm{s}}=$ fresh volume of the subsample of the stem.

The fresh weight of other fractions were converted into dry weight by using the ratio of subsample dry weight and subsample fresh weight as indicated in the formula of Jarayaman (2000).

$D W_{f}=F_{f} \times D W_{s} / F W_{s}$. Where, $D W_{f}=$ dry weight of the fraction, $F W_{f=}$ fresh weight of the fraction, $D W_{s}=$ dry weight of the subsample of the fraction, and $\mathrm{FW}_{\mathrm{s}}=$ fresh weight of the subsample of the fraction. Then, the sample tree dry weight is the sum of the dry weight of fractions.

Mechanical wood properties:

Bolts of approximately $50 \mathrm{~cm}$ length were taken at three height levels of the tree: bottom, middle and top. These bolts were used as samples for the evaluation of mechanical properties of Khaya senegalensis as plantations in $5 \times 5 \mathrm{~m}$ or as single row at $5 \mathrm{~m}$ spacing. Four boards with nominal thickness of $3 \mathrm{~cm}$ were sawn from each bolt obtained from the trees. The boards were cut parallel to the anatomical planes of wood. Then sticks of $2 \mathrm{~cm} \times 2 \mathrm{~cm}$ were prepared and labeled according to tree number. All wood sticks were then stacked to air dry in the testing room at $20 \pm 2^{\circ} \mathrm{C}$ and $65 \pm 3 \%$ relative humidity until the specimens were reached to the equilibrium moisture content of $12 \%$ MC. Testing of mechanical properties namely, static bending (modulus of rupture and modulus of elasticity), compression parallel to grain and shear parallel to grain were conducted in accordance with ISO- 3133 (Anonymous, 1975c), ISO- 3787 (Anonymous, 1976a) and ISO- 3347 (Anonymous, 1976b) standard, respectively. The studied tests of air-dried $20 \times 20 \mathrm{~mm}$ (cross section) and $30 \mathrm{~mm}$ long specimens were performed by using a general testing machine (LR $50 \mathrm{~K}$ ) attached to a computer, in testing room with standard condition of $20 \pm 2^{\circ} \mathrm{C}$ and $65 \pm 3 \%$ relative humidity.

Data of above-ground biomass and mechanical wood properties were pooled to compute the overall minimum, maximum, mean and standard deviation of these characters.

\section{RESULTS AND DISCUSSION}

\section{Biomass determination:}

Total stem volume, diameter at breast height, merchantable height and total height of Khaya senegalensis grown either at $5 \times 5 \mathrm{~m}$ spacing or as single row are given in Table 1. The results of the Table pointed out that, these measurements were increased for $K$. senegalensis grown as a single- tree row compared to that grown as plantations at $5 \times 5 \mathrm{~m}$ spacing. Total stem volume for trees grown at $5 \times 5 \mathrm{~m}$ spacing ranged from 0.55 to $3.40 \mathrm{~m}^{3} /$ tree with an average of $1.79 \pm 0.65 \mathrm{~m}^{3} /$ tree, while it ranged from 3.40 to $4.50 \mathrm{~m}^{3} /$ tree for trees grown as a single row with an average of $3.9 \pm 0.73 \mathrm{~m}^{3} /$ tree . However, the mean of diameter at breast height, merchantable height and total height was $40.45 \mathrm{~cm}, 18.55 \mathrm{~m}$ and $22.39 \mathrm{~m}$ for trees grown at $5 \times 5 \mathrm{~m}$ spacing, while it was $60.38 \mathrm{~cm}, 23.07 \mathrm{~m}$ and $25.20 \mathrm{~m}$ for trees in a single row, respectively. 
Table (1): Total stem volume $\mathrm{m}^{3} /$ tree, diameter at breast height $(\mathrm{cm})$, merchantable height $(\mathrm{m})$ and total height $(\mathrm{m})$ for Khaya senegalensis grown at $5 \times 5 \mathrm{~m}$ or as single row at $5 \mathrm{~m}$ spacing.

\begin{tabular}{|c|c|c|c|c|c|c|c|c|}
\hline \multirow[t]{2}{*}{ Properties } & \multicolumn{4}{|c|}{$\begin{array}{c}\text { K. senegalensis at } 5 \times 5 m \\
\text { spacing }\end{array}$} & \multicolumn{4}{|c|}{$\begin{array}{c}\text { K. senegalensis as single } \\
\text { row }\end{array}$} \\
\hline & Min & Max & Mean & SD & Min & Max & Mean & SD \\
\hline Total stem volume & 0.55 & 3.40 & 1.79 & 0.65 & 3.40 & 4.35 & 3.90 & 0.73 \\
\hline Diameter at breast height & 39.17 & 41.68 & 40.45 & 9.80 & 56.14 & 63.03 & 60.38 & 10.90 \\
\hline Merchantable height & 17.25 & 19.20 & 18.55 & 3.80 & 21.46 & 24.35 & 23.07 & 4.10 \\
\hline Total height & 21.43 & 23.64 & 22.39 & 4.90 & 23.45 & 26.65 & 25.20 & 5.30 \\
\hline
\end{tabular}

The fresh weight of total biomass, leaves, twigs up to $1 \mathrm{~cm}$, and small branches up to $5 \mathrm{~cm}$ as well as main stem of 36- year- old $K$. senegalensis planted at $5 \times 5 \mathrm{~m}$ or as a single row at $5 \mathrm{~m}$ spacing are presented in Table 2 . The fresh weight of total biomass ranged from 2355.6 to $2420.7 \mathrm{~kg} /$ tree and the average was $2380.1 \pm 380 \mathrm{~kg} /$ tree for trees at $5 \times 5 \mathrm{~m}$ spacing, while it ranged from 5496.2 to $5554.2 \mathrm{~kg} /$ tree with an average of $5521.8 \pm 465 \mathrm{~kg} /$ tree for that grown as a single- tree row. For $K$. senegalensis at $5 \times 5 \mathrm{~m}$ spacing, the mean fresh weight of leaves, twigs, small branches and main stem were 204.6, $368.9,367.8$ and $1438.9 \mathrm{~kg} /$ tree, respectively, while they were $317.2,548.9,1261.4$ and $3394.3 \mathrm{~kg} /$ tree for those grown as a single row, respectively. In general, the characters of biomass fresh weight of 36year- old $K$. senegalensis planted in single- row at $5 \mathrm{~m}$ spacing were higher than the biomass ranges of the same species at $5 \times 5 \mathrm{~m}$ spacing.

Table (2): Fresh weights $(\mathrm{kg})$ of total biomass, leaves, twigs up to $1 \mathrm{~cm}$ diameter, branches up to $5 \mathrm{~cm}$ diameter and main stem up to merchantable diameter for Khaya senegalensis grown at $5 \times 5 \mathrm{~m}$ or as single row at $5 \mathrm{~m}$ spacing.

\begin{tabular}{|l|c|c|c|c|c|c|c|c|}
\hline \multirow{2}{*}{ Properties } & \multicolumn{4}{|c|}{ K. senegalensis at 5x5m } & \multicolumn{3}{c|}{ K. senegalensis as single } \\
& \multicolumn{4}{|c|}{ spacing } & \multicolumn{4}{c|}{ row } \\
\cline { 2 - 9 } & Min & Max & Mean & SD & Min & Max & Mean & SD \\
\hline Total biomass & 2355.6 & 2420.7 & 2380.1 & 380 & 5496.2 & 5554.2 & 5521.8 & 465 \\
\hline Leaves & 192.4 & 224.7 & 204.6 & 67.9 & 303.0 & 325.9 & 317.2 & 81.7 \\
\hline Twigs up to 1cm diameter & 331.4 & 395.2 & 368.9 & 87.6 & 501.7 & 586.4 & 548.9 & 96.3 \\
\hline $\begin{array}{l}\text { Branches up to 5 cm } \\
\text { diameter }\end{array}$ & 340.3 & 404.4 & 367.8 & 88.9 & 1215.1 & 1305.3 & 1261.4 & 117 \\
\hline $\begin{array}{l}\text { Main stem } \\
\text { Min= Minimum }\end{array}$ & 1396.3 & 1470.5 & 1438.9 & 290 & 3349.1 & 3433.6 & 3394.3 & 328 \\
\hline
\end{tabular}

The minimum, maximum, mean and standard deviation values of dry weight of leaves, branches up to $5 \mathrm{~cm}$ diameter and main stem for 36-y- old $K$. senegalensis planted at $5 \times 5 \mathrm{~m}$ or as a single- tree row at $5 \mathrm{~m}$ spacing are summarized in Table 3. Generally, the dry weight of biomass characters of the trees that planted in single row at $5 \mathrm{~m}$ spacing was higher than that of trees grown in plantations at $5 \times 5 \mathrm{~m}$ spacing. The average values for leaves, small branches and main stem were $98.9 \pm 14.6, \quad 186.3 \pm 78.7$ and $738.7 \pm$ $197 \mathrm{~kg} /$ tree, respectively for plantations at $5 \times 5 \mathrm{~m}$ spacing. These values are 
Ebeid, A. F. A. et al.

lower than those of trees planted as a single row which recorded $153.2 \pm$ $19.8,637.7 \pm 93.5$ and $1738.9 \pm 218 \mathrm{~kg} /$ trees for the same characters, respectively.

From these results about biomass yield, $K$. senegalensis planted as a single row resulted in higher values than that of trees at $5 \times 5 \mathrm{~m}$ spacing assuming that nutrient and water is limited and maximum sunlight is desirable for growth, widely spaced trees will grow faster than crowded ones. When this relationship is combined with the knowledge that growth rate in tree species is related to the tree spacing, it is easy to see the differences between biomass characters of the studied trees. Our results are in a good agreement with the previous study of El- Morshedy et al. (1996) on the same plantations at 28-year- old. They also reported that for planted area, the predicted yield per feddan is $181.4 \mathrm{~m}^{3}$ for total stem volume and $36.1 \pm 5.9$ ton/ fed for branches fresh weight, while for the single- tree row the predicted yield is $510.7 \mathrm{~m}^{3} /$ fed for total stem volume and $108.4 \pm 24.4 \mathrm{ton} / \mathrm{fed}$ for branches fresh weight.

Table (3): Dry weight $(\mathrm{kg})$ of leaves, branches up to $5 \mathrm{~cm}$ diameter and main stem up to merchantable diameter for Khaya senegalensis grown at $5 \times 5 \mathrm{~m}$ or as single row at $5 \mathrm{~m}$ spacing.

\begin{tabular}{|c|c|c|c|c|c|c|c|c|}
\hline \multirow[t]{2}{*}{ Properties } & \multicolumn{4}{|c|}{$\begin{array}{c}\text { K. senegalensis at } 5 \times 5 \mathrm{~m} \\
\text { spacing }\end{array}$} & \multicolumn{4}{|c|}{$\begin{array}{l}\text { K. senegalensis as single } \\
\text { row }\end{array}$} \\
\hline & \begin{tabular}{|l|} 
Min \\
\end{tabular} & Max & Mean & SD & Min & Max & Mean & SD \\
\hline DYoc & 93.0 & 108.0 & \begin{tabular}{|l|}
98.9 \\
\end{tabular} & 14.6 & 145.7 & 156.7 & 153.2 & 19.8 \\
\hline $\begin{array}{l}\text { ranches up to } \\
\text { ameter }\end{array}$ & $\begin{array}{ll}5 \mathrm{~cm} & 172.7\end{array}$ & 204.2 & 186.3 & 78.7 & 613.7 & 662.6 & 637.7 & 93.5 \\
\hline Main stem & 712.4 & 4 & 738.7 & 197 & 1708.7 & 1760.8 & 1738.9 & 218 \\
\hline
\end{tabular}

Min= Minimum $\quad$ Max $=$ Maximum $\quad$ SD $=$ Standard deviation

\section{Mechanical properties:}

The ranges, means and standard deviations of the mechanical properties of 36-y- old $K$. senegalensis planted at $5 \times 5 \mathrm{~m}$ spacing or as a single- tree row at $5 \mathrm{~m}$ spacing are tabulated in Table 4. Generally, the strength properties of $K$. senegalensis grown in plantations at $5 \times 5 \mathrm{~m}$ spacing resulted in higher values than those grown as a single- tree row. The average values for modulus of rupture (MOR), modulus of elasticity (MOE), compression parallel to grain and maximum shearing strength of trees at $5 \times 5$ $\mathrm{m}$ spacing were 124.6, 12596, 63.1 and $15.8 \mathrm{~N} / \mathrm{mm}^{2}$, while it were 110.1, $10681,57.9$ and $13.0 \mathrm{~N} / \mathrm{mm}^{2}$ for that grown as a single row, respectively. The strength properties of mature $K$. senegalensis grown in southern Egypt are almost comparable to other mature valuable hardwood species grown in different countries as reported by Keating and Bolza (1982) and Josue (2004). From this comparison, the values for modulus of rupture, compression parallel to grain and maximum shearing strength of $K$. senegalensis plantations are lower than that of Eusideroxylon zwageri, Shorea laevis and Xylia xylocarpa, but are higher than Intsia palembanica and Vatica cuspidate. Meanwhile, the mean modulus of elasticity (MOE) of 36 -year- old $K$. senegalensis is low in comparison to the other species. 
However, the differences between wood strength properties of trees in plantations or in a single row my be related to the differences in their density. Haygreen and Bowyer (1996) pointed out that, within any species there is a considerable variation in clear wood strength properties, which corresponds to the variation in density and to the density- strength relationship for that property.

Table (4): Mechanical properties of Khaya senegalensis grown at $5 \times 5 \mathrm{~m}$ or as single row at $5 \mathrm{~m}$ spacing.

\begin{tabular}{|l|c|c|c|c|c|c|c|c|}
\hline \multirow{2}{*}{ Properties } & \multicolumn{3}{c|}{ K. senegalensis at 5x5m } & \multicolumn{4}{c|}{ K. senegalensis as } \\
& spangle row \\
\cline { 2 - 9 } & Min & Max & Mean & SD & Min & Max & Mean & SD \\
\hline MOR $\left(\mathrm{N} / \mathrm{mm}^{2}\right)$ & 118.6 & 131.4 & 124.6 & 20.4 & 91.2 & 114.6 & 110.1 & 16.8 \\
\hline MOE $\left(\mathrm{N} / \mathrm{mm}^{2}\right)$ & 10530 & 13290 & 12596 & 1780 & 9589 & 11802 & 10681 & 1611 \\
\hline Compression $\left(\mathrm{N} / \mathrm{mm}^{2}\right)$ & 43.5 & 73.8 & 63.1 & 6.8 & 39.4 & 68.3 & 57.9 & 5.9 \\
\hline Shear $\left(\mathrm{N} / \mathrm{mm}^{2}\right)$ & 11.7 & 23.9 & 15.8 & 3.8 & 10.4 & 20.5 & 13.0 & 3.1 \\
\hline
\end{tabular}

Min= Minimum Max= Maximum $\mathrm{SD}=$ Standard deviation

MOR= Modulus of rapture MOE= Modulus of elasticity

Compression= Compression parallel to grain (maximum crushing strength)

Shear= Shear parallel to grain (maximum shearing strength)

\section{Conclusion}

Our results revealed that, the productivity potential of 36-year- old $K$. senegalesnis grown under Aswan conditions at $5 \times 5 \mathrm{~m}$ spacing was about $300.7 \mathrm{~m}^{3} / \mathrm{fed}, 61.8 \mathrm{ton} / \mathrm{fed}, 61.9 \mathrm{ton} / \mathrm{fed}$ and $34.3 \mathrm{ton} / \mathrm{fed}$ for total stem volume, branches up to $5 \mathrm{~cm}$ diameter, twigs up to $1 \mathrm{~cm}$ and fresh leaves, respectively. Also, $K$. senegalensis trees when planted along roadsides, on the banks of the river Nile and canals and around fields to strengthen the economy of Egypt, this tree should produce about $780 \mathrm{~m}^{3} / \mathrm{Km}$ and 252.3 ton/ $\mathrm{Km}$ for total stem volume and branches up to $5 \mathrm{~cm}$ diameter, respectively at 36-year- old.

Generally, the mechanical properties of $K$. senegalensis planted in Aswan were comparable of a number of valuable hardwood species such as Eusideroxylon zwageri, Instia palembanica, Shorea laevis, Vatica cuspidate and Xylia xylocarpa, indicating its suitability for heavy construction and different uses. This study further reinforces the fact that number of woody species in Egypt as general and $K$. senegalensis in particular could be potential source of commercial timber. Results of the present study may be useful in the choice of species for establishing forest plantations and afforestation programs.

\section{REFERENCES}

Anonymous 1975 c. Wood determination of ultimate strength in static bending. ISO $3133-1975$ (E), 2 pp.

Anonymous 1976 a. Wood tests methods- determination of ultimate stress in compression parallel to grain. ISO $3787-1976(E), 2$ pp.

Anonymous $1976 \mathrm{~b}$. Wood determination of ultimate shearing stress parallel to grain. ISO $3347-1976(\mathrm{E}), 1 \mathrm{p}$. 
Ebeid, A. F. A. et al.

Cannell, M.G.R. 1982. World forest biomass and primary production data. Academic, London, $220 \mathrm{pp}$.

de Gier, A. 2003. A new approach to woody biomass assessment in woodlands and shrub lands. In: P.Roy (Ed), Geoinformatics for Tropical Ecosystems, India, pp. 161-198.

El- Morshedy, M.M.; Abd El- Dayem, A.M. and Shehata, M.S. 1996. Evaluation of biomass and some physical properties of Khaya senegalensis grown in south Egypt. The $4^{\text {th }}$ Arab. Conf. for Hort. Crops, 25-28 March 1996, Fac. Agric. Minia Univ., Egypt

FAO 2004b. National Forest Inventory: Field manual template, Rome. (Online) http: //www.fao.org/ docrep/ 008/ ae 578e/ ae 578e 00.htm (Accessed on December 15, 2006).

Guler, C.; Coper Y.; Akgul, M. and Buyuksari, U. 2007. Some chemical, physical and mechanical properties of juvenile wood from black pine (Pinus nigra Arnold) plantations. Appl. Sci. J. 7 (5): 755- 758.

Haygreen, J.G. and Bowyer, J.L. 1996. Forest Products and Wood Science. 3 rd ed. lowa State Univ. Press/ Ames, pp. 213-242.

Jarayaman, K. 2000. Statistical Manual for Forestry Research, FORSPA/ FORSPA/ FAO.(Online) http: //www. Fao. Org/ docrep/ 003/ x6831e/ x6831e 00.htm (Accessed on December 5, 2006.

Josue, J. 2004. Some wood properties of Xylia xylocarpa planted in Sabah. Sepilok Bulletin 1: 1-15.

Keating, W.G. and Bolza, E. 1982. Characteristics, properties and uses of timbers. Vol. 1. South East Asia, Northern Australia and the Pacific. CSIRO, Melbourne.

Ketterings, Q.M.; Coe, R.; Noordwijk, M.Van; Ambagan, Y. and Palm, C.A 2001. Reducing uncertainty in the case of allometric biomass equations for predicting above-ground tree biomass in mixed secondary forests. Forest Ecology and Management, 146 (1-3): 199-209.

Kretshmann, D.E. and Green, D.W. 1996. Modeling moisture contentmechanical property relationships for clear Southern Pine. Wood and Fiber Science. 28(3): 320-337.

Losi, C.J.; Siccama, T.G.; Condit, R. and Morales, J.E. 2003. Analysis of alternative methods for estimating carbon stock in young tropical plantations. Forest Ecology and Management, 184 (1-3): 355-368.

Mallory, M.P. and Gramer, S. 1987. Fracture mechanics: a tool for predicting wood component strength. Forest Products J. 37 (7/ 8): 39-47.

Nasser, R.; H. Al- Meffarrej; Abdel- Aal, M. and Hegazy, S. 2010. Chemical and mechanical properties of Melia azedarach mature wood as affected by primary treated sewage- effluent irrigation. AmericanEurasian J. Agric. \& Environ. Sci., 7 (6): 697- 704.

Parresol, R. 1999. Assessing Tree and Stand Biomass: A Review with Examples and Critical Comparisons. Forest Science, 45: 573-593.

Sahni, K.C. 1968. Important trees of the northern Sudan. United Nations and FAO. 
امكانية الانتاجية وبعض خصائص الخثب الميكانيكية للكايا السنغالى عمر ب بـ سنة

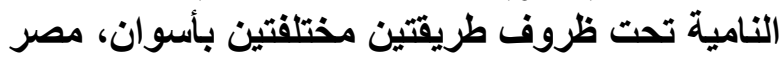

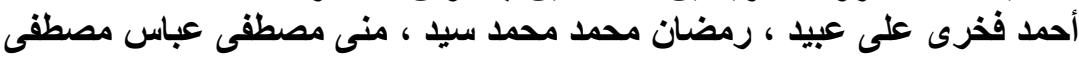

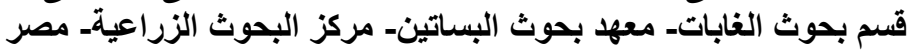

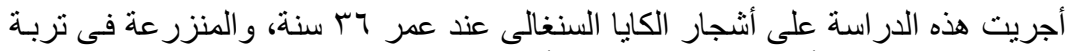

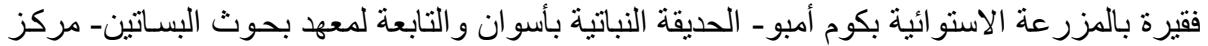

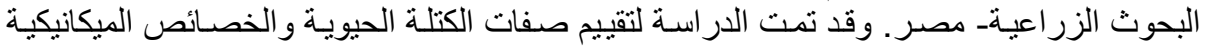

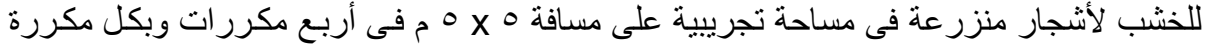

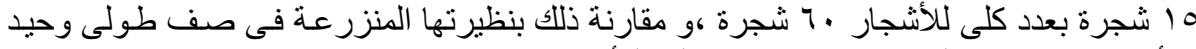

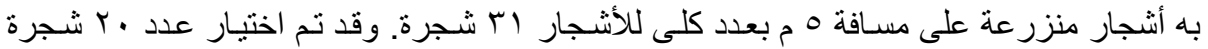

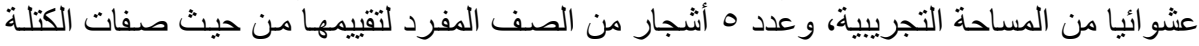

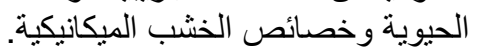

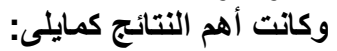

ـ تفوقت الأشجار المنزرعة فى صف طولى مقارنة بمثيلتها المنزر عة كمساحة تجريبية فى صفات

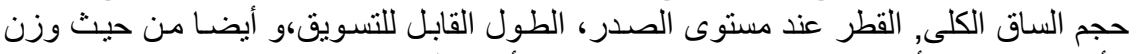

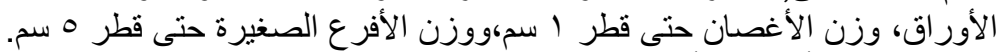

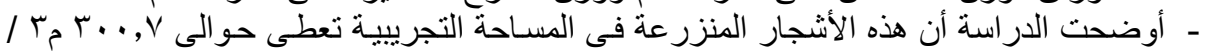

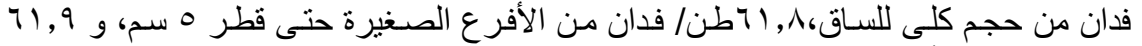

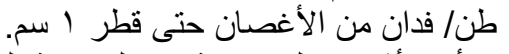

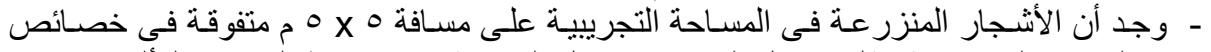

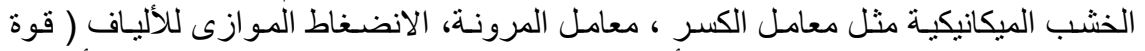

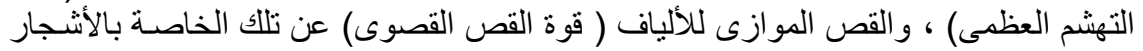

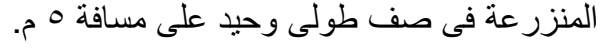

كلية الزراعة - جامعة المنصورة كلية الزراعة - جامعة كفر الثيخ الزيخ

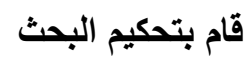

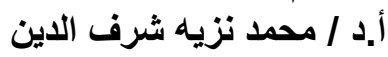

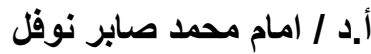

